\title{
Relative Salt Tolerance of Five Herbaceous Perennials
}

\author{
Genhua Niu ${ }^{1}$ and Denise S. Rodriguez
}

Department of Horticultural Sciences, Texas A\&M University, El Paso Agricultural Research and Extension Center, 1380 A\&M Circle, El Paso, TX 79927

Additional index words. Achillea millefolium, Agastache cana, Echinacea purpurea, Gaillardia aristata, landscape irrigation, Salvia coccinea, water reuse

\begin{abstract}
Use of recycled water to irrigate urban landscapes may be inevitable, because the freshwater supply has been diminishing and the population continues to grow in the arid and semiarid southwestern United States. However, little information exists on the performance of landscape plants irrigated with nonpotable water. Two greenhouse studies were conducted during the summer and the fall to characterize the relative salt tolerance of five herbaceous perennials by irrigating the plants with a saline solution at an electrical conductivity (EC) of $0.8 \mathrm{dS} \cdot \mathrm{m}^{-1}$ (tap water), $2.0 \mathrm{dS} \cdot \mathrm{m}^{-1}$, or $4.0 \mathrm{dS} \cdot \mathrm{m}^{-1}$. In the summer study, after 10 weeks of treatment, Achillea millefolium L., Gaillardia aristata Foug., and Salvia coccinea Juss ex J. had an aesthetically acceptable appearance for landscape performance (visual quality scores of 4 points or more), whereas Agastache cana (Hook.) Woot. \& Standl. and Echinacea purpurea (L.) Moench had relatively low tolerance to salinity. Dry weight of shoots of $A$. millefolium, $A$. cana, and $G$. arstata was lower at elevated salinity levels. In the fall study, A. millefolium, E. purpurea, G. arstata, and $S$. coccinea had acceptable growth and visual quality at elevated salinity levels, whereas $A$. cana had lower quality and reduced growth. Dry weight of shoots was lower in G. arstata and $A$. millefolium at an EC of $2.0 \mathrm{dS} \cdot \mathrm{m}^{-1}$ or $4.0 \mathrm{dS} \cdot \mathrm{m}^{-1}$. Leaf osmotic potential of all species in the summer experiment was significantly lower at higher salinity compared with the control. In the fall experiment, leaf osmotic potential in A. millefolium, E. purpurea, and $G$. aristata at $4 \mathrm{dS} \cdot \mathrm{m}^{-1}$ was lower compared with lower salinity treatment and the control. Leaf osmotic potential in the fall was higher than that of the same species at the same salinity level in the summer experiment, indicating that plants in the fall were less stressed than in the summer. Combined the results from both experiments, the authors concluded that $\boldsymbol{A}$. millefolium, $\boldsymbol{G}$. arstata, and $S$. coccinea had a relatively high salt tolerance (as much as $\mathbf{4} \mathbf{d S} \cdot \mathrm{m}^{-1}$ of irrigation water under greenhouse conditions) among the tested species, whereas $A$. cana and $E$. purpurea were not tolerant to salt and should not be irrigated with low-quality water.
\end{abstract}

Urban landscape water conservation has become increasingly important throughout the southwestern region of the United States as a result of limited water supplies. With the rapid increase in urban populations and industrial development, the demand for fresh water will become more difficult to meet in the future. Applying treated effluent to irrigate landscapes can conserve a substantial amount of potable water because $\approx 50 \%$ of the total municipal water consumption from May through Oct. in the Southwest is used for landscape irrigation (Kjelgren et al., 2000). It was reported recently that $60 \%$ to $90 \%$ of total water use by single-family residences is allocated to landscape irrigation in the urban areas of the Southwest (Sovocool et al., 2006).

Received for publication 8 May 2006. Accepted for publication 24 June 2006. This project was supported in part by the Cooperative State Research, Education and Extension Service, U.S. Department of Agriculture under agreement no. 2005-3446115661 .

${ }^{1}$ To whom reprint requests should be addressed; e-mail gniu@ag.tamu.edu.
In addition to a limited freshwater supply, wastewater disposal is another growing concern. Treated municipal effluent is the only water source that increases with urban population growth (Qian et al., 2005). Using treated effluent for landscape irrigation could help wastewater disposal. Land application of industrial and municipal wastewater has shown to be an environmentally safe water management strategy (Rodriguez, 2005; Ruiz et al., 2006).

Treated effluents have been used for decades for irrigating golf courses and some agronomic crops in many areas of the United States (Rhoades, 1999) and other countries (Pasternak and Malach, 1994). Some treated effluent may contain nutrients essential for plant growth, thereby reducing fertilizer costs. It has been reported that the quality of some cut flower species may be improved by saline water irrigation (Shillo et al., 2002).

The major concern in using treated effluents for landscape irrigation is the elevated salinity, which is usually two to three times higher than potable water (Khurram and Miyamoto, 2005; Wu et al., 2001). This elevated salinity can affect the performance of salt-sensitive landscape plants. Foliage injury, including leaf burn and leaf necrosis, is a common symptom when plants were irrigated with treated effluents or low-quality water (Jordan et al., 2001, Wu et al., 2001). Salt tolerance of landscape plants is highly variable, depending on the species or even the cultivar, climatic conditions, and irrigation method (Fox et al., 2005; Parnell, 1988; $\mathrm{Wu}$ et al., 2001). An increasing number of landscapes have switched to or plan to use recycled wastewater for irrigation in the western states (Qian et al., 2005). Because a typical landscape consists of multiple plant species, it is imperative to determine the salt tolerance of commonly used landscape plants to minimize potential salt damage before converting to treated effluents or any other nonpotable water source. Salt tolerance of many agricultural crops has been reported (Ulery et al., 1998), but limited information exists for landscape plants.

To conserve water, many municipalities in the Southwest encourage homeowners and businesses to reduce turf coverage in landscapes with incentive programs (e.g., El Paso, Texas, and Las Vegas, Nev.). An alternative to turf may be the low-water use herbaceous perennials and groundcover species or mulch. Some nurseries in the Southwest have increased the variety of herbaceous perennials recently (J. Harvey, Sunland Nursery, N.M., pers. comm., Sept. 2005). In fact, herbaceous perennials have been popular commodities for landscapes because of low maintenance and increasing diversity in landscapes (Cameron et al., 2000; Johnson and Whitwell, 1997).

We investigated the relative salt tolerance of five herbaceous perennials: Achillea millefolium (yarrow), Agastache cana (wild hyssop), Echinacea purpurea (purple coneflower), Gaillardia aristata (firewheel), and Salvia coccinea (scarlet sage). A. millefolium is native to Europe and western Asia and is widely naturalized in temperate regions (Zhang et al., 1996). All other species are native to the southwestern United States (Bailey and Bailey, 1976). The objective of this study was to provide baseline information on the relative salt tolerance of these species by growing them in the greenhouse at three salinity levels in two separate studies. Growth, visual quality, and leaf osmotic potential in response to salinity were examined.

Table 1. Electrical conductivity (EC), $\mathrm{Na}, \mathrm{Ca}, \mathrm{Mg}$, and $\mathrm{Cl}$ concentrations of the saline solutions for both summer and fall experiments.

\begin{tabular}{lcccccc}
\hline Treatment & $\mathrm{EC}\left(\mathrm{dS} \cdot \mathrm{m}^{-1}\right)$ & $\mathrm{Na}(\mathrm{mM})$ & $\mathrm{Ca}(\mathrm{mm})$ & $\mathrm{Mg}(\mathrm{mm})$ & $\mathrm{Cl}(\mathrm{mm})$ & $\mathrm{SO}_{4}(\mathrm{~mm})$ \\
\hline Control & $0.8^{\mathrm{z}}$ & 8 & 1.3 & 0.3 & 6.3 & 1.1 \\
EC 2 & 2.0 & 19 & 0.6 & 1.5 & 20 & 0.7 \\
EC 4 & 4.0 & 38 & 1.3 & 3.0 & 40 & 1.4 \\
\hline
\end{tabular}

${ }^{\mathrm{z}}$ Analytical results of tap water were provided by local water utilities. 


\section{Materials and Methods}

\section{Plant culture}

Two separate greenhouse experiments were conducted during the summer and fall seasons. Seeds of A. millefolium, A. cana, $E$. purpurea, $G$. aristata, and $S$. coccinea were purchased from a nursery (Plants of the Southwest, Albuquerque, N.M.) and sown on 10 Mar. in plug trays filled with Sunshine Mix no. 5 (SunGro Hort., Bellevue, Wash.) for the summer experiment. Seedlings were transplanted on 7 June to 1.8 -L round plastic containers filled with Sunshine Mix no. 4 (SunGro Hort.) containing Canadian sphagnum peatmoss, fine perlite, starter nutrients, gypsum, powdered dolomitic limestone, and a wetting agent. Plants were placed on greenhouse benches and subirrigated with tap water until treatments were initiated on 15 June. A controlled-release fertilizer, Osmocote, $14 \mathrm{~N}-6.4 \mathrm{P}-11.6 \mathrm{~K}$ (Scotts-Sierra Horticultural Products, Marysville, Ohio) was applied at a rate of $4.6 \mathrm{~g} \cdot \mathrm{L}^{-1}$. The air temperature during the summer experimental period was maintained at $29 \pm 3{ }^{\circ} \mathrm{C}$ during the day and $22 \pm 2{ }^{\circ} \mathrm{C}$ at night measured by thermocouples. The daily light integral (DLI, $P A R)$ was measured at $16 \pm 2 \mathrm{~mol} \cdot \mathrm{m}^{-2} \cdot \mathrm{d}^{-1}$ by a quantum sensor (Model QSO-SUN; Apogee Instruments, Logan, Utah). A 21X datalogger (Campbell Scientific, Logan, Utah) was used to measure temperature and light every $10 \mathrm{~s}$ and record the hourly average.

In the fall experiment, seeds of $A$. millefolium, A. cana, E. purpurea, G. aristata, and $S$. coccinea from the same nursery were sown in plug trays on 29 June. Seedlings were transplanted on 2 Aug. to $500-\mathrm{mL}$ pots filled with the same medium described previously. Because the 1.8-L container was too small for rapidly growing species (A. millefolium, $G$. aristata, and $S$. coccinea), in the fall study seedlings were transplanted on 20 Sept. to 2.6-L containers filled with a volume-tovolume blend of 1 Sunshine Mix no. 4:1 composted mulch (Western Organics, Tempe. Ariz.). Composted mulch was added to the medium to improve drainage. The same controlled-release fertilizer was applied at $4.6 \mathrm{~g} \cdot \mathrm{L}^{-1}$. The average air temperatures in the greenhouse during the fall experiment were maintained at $23 \pm 2{ }^{\circ} \mathrm{C}$ during the day and $19 \pm 2{ }^{\circ} \mathrm{C}$ at night, and the DLI was $10 \pm$ $2 \mathrm{~mol} \cdot \mathrm{m}^{-2} \cdot \mathrm{d}^{-1}$

\section{Salinity treatment}

Three salinity levels $-0.8 \mathrm{dS} \cdot \mathrm{m}^{-1}$ (tap water), $2.0 \mathrm{dS} \cdot \mathrm{m}^{-1}$, and $4.0 \mathrm{dS} \cdot \mathrm{m}^{-1}$ electrical conductivity (EC) were created by adding $\mathrm{NaCl}, \mathrm{MgSO}_{4} \cdot 7 \mathrm{H}_{2} \mathrm{O}$, and $\mathrm{CaCl}_{2}$ to reverseosmosis (RO) water (Table 1). EC at $2 \mathrm{dS} \cdot \mathrm{m}^{-1}$ is similar to that of local reclaimed water. Salinity treatments were initiated on 15 June for summer experiment by subirrigation and ended on 24 Aug. The composition of the saline solution was similar to that of the reclaimed municipal effluent of the local water utilities. In the fall experiment, treatments were initiated on 5 Oct. and ended on 14 Dec. with the same salinity treatments by

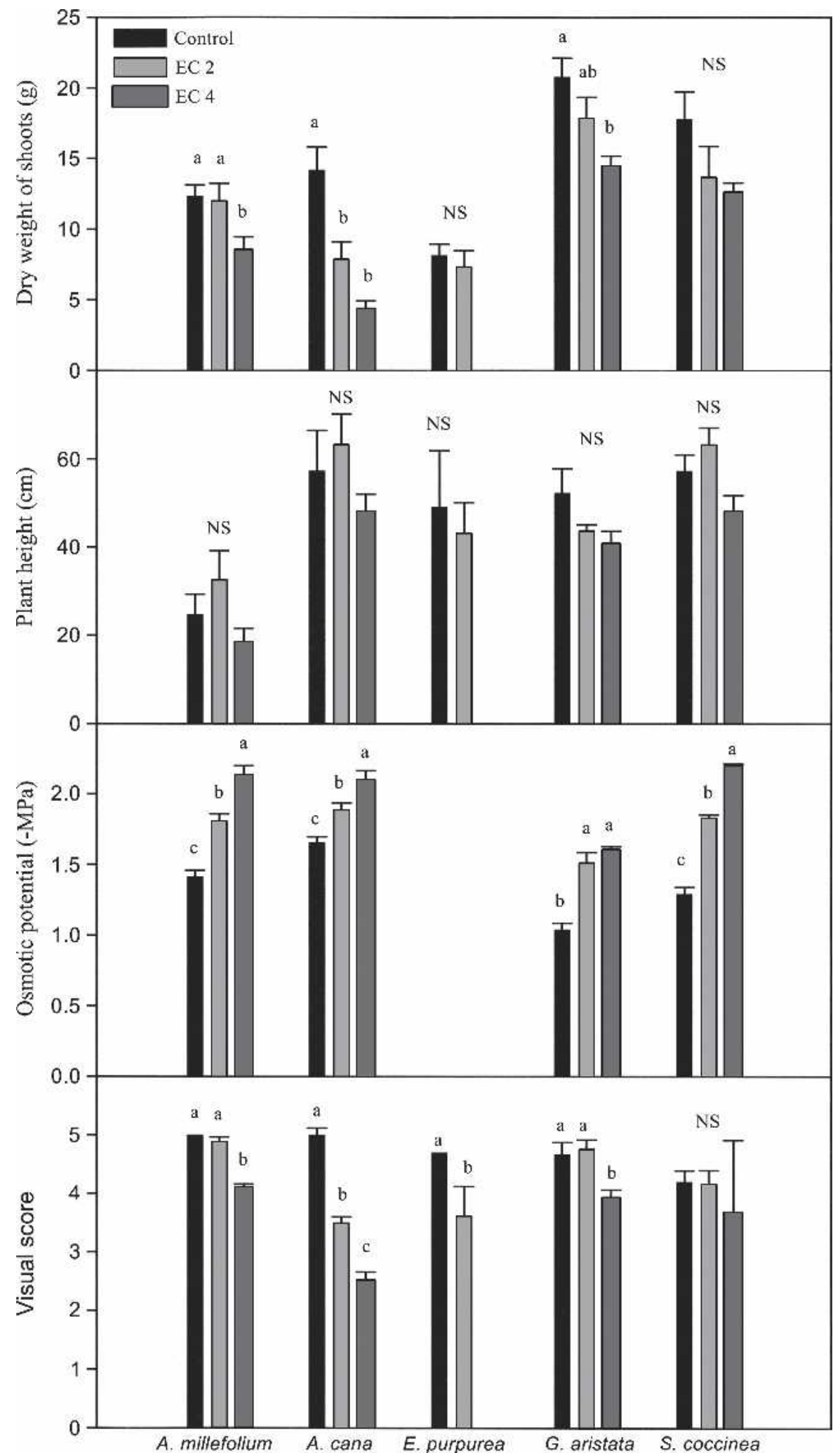

Fig. 1. Effect of electrical conductance (EC) of irrigation solution on dry weight of shoots, plant height, leaf osmotic potential, and visual score of Achillea millefolium, Agastache cana, Echinacea purpurea, Gaillardia aristata, and Salvia coccinea in the summer experiment. Means within each species followed by the same letters are not significantly different, tested by Student-Newman-Keuls multiple comparison at $P=0.05$. Vertical bars represent SE. NS, no significant among treatment. Control, tap water; EC2, EC at $2.0 \mathrm{dS} \cdot \mathrm{m}^{-1} ; \mathrm{EC} 4, \mathrm{EC}$ at $4 \mathrm{dS} \cdot \mathrm{m}^{-1}$.

surface irrigation with a leaching fraction of $\approx 45 \%$ for all species. Because water use was species dependent, plants were irrigated by species when the medium surface started to dry for that species in both experiments to avoid drought stress. Plant species were 
randomly placed on greenhouse benches and were rotated weekly to minimize the differences in microenvironment. There were six replicates in each salinity treatment in a completely randomized design for both experiments.

\section{Measurements}

Upon termination of each experiment, plant height, visual quality, and dry weight of shoots were measured. Visual quality of plants was assessed by two persons on a scale of 1 to 5 points, where 1 is severely stunted growth with more than $50 \%$ foliage salt damage (leaf necrosis, browning) or dead, 2 is somewhat stunted growth with moderate $(25 \%$ to $50 \%)$ foliage salt damage, 3 is average quality with slight $(<25 \%)$ foliage salt damage, 4 is good quality with acceptable growth reduction and little foliage damage (acceptable as landscape performance), and 5 is excellent with vigorous growth and no foliage damage. The dry weight of shoots was determined by oven drying the tissue for $48 \mathrm{~h}$ at $70{ }^{\circ} \mathrm{C}$. Leachate EC was determined during and at the end of the experiment according to the pour-through method (Wright, 1986). Specifically, $50 \mathrm{~mL}$ or 100 $\mathrm{mL} \mathrm{RO}$ water was added to 1.8 -L or $2.6-\mathrm{L}$ containers, respectively, through the surface of the medium, and leachate was collected and analyzed for EC using a salinity meter (model B-173; Horiba, Ltd., Kyoto, Japan). Analysis of leachate EC was conducted for three containers per treatment per species and data were pooled across the species for each salinity treatment.

Leaf osmotic potential $\left(\psi_{\mathrm{s}}\right)$ was determined on four well-watered plants per species per treatment by sampling leaves at the midsection of a shoot in the early morning (8:00 to 9:00 AM). Leaf tissue was sealed in a plastic bag and immediately stored in a $-80{ }^{\circ} \mathrm{C}$ freezer until analysis. Frozen tissue was thawed in the plastic bag at room temperature before sap was pressed with a Markhart leaf press (LP-27; Wescor, Logan, Utah) and the sample was analyzed for $\psi_{\mathrm{S}}$ using a vapor pressure osmometer (Vapro model 5520; Wescor) to determine the tissue $\psi_{\mathrm{S}}$. Osmometer readings (in millimoles per kilogram) were converted to MPa (Mega Pascals) using the van't Hoff equation at $25{ }^{\circ} \mathrm{C}$ (Nobel, 1991).

Data were analyzed separately for the two experiments. The significance among salinity treatments on dry weight, plant height, $\psi_{\mathrm{S}}$, and visual scores was analyzed by StudentNewman-Keuls multiple comparison at $P=$ 0.05 for each species using SAS software (SAS Institute, Cary, N.C.).

\section{Results and Discussion}

In the summer experiment, dry weight of shoots of A. millefolium, A. cana, and G. aristata were significantly less at $2 \mathrm{dS} \cdot \mathrm{m}^{-1}$ or $4 \mathrm{dS} \cdot \mathrm{m}^{-1}$, or at both compared with the control (Fig. 1). Although dry weight of $S$. coccinea tended to decrease as salinity of

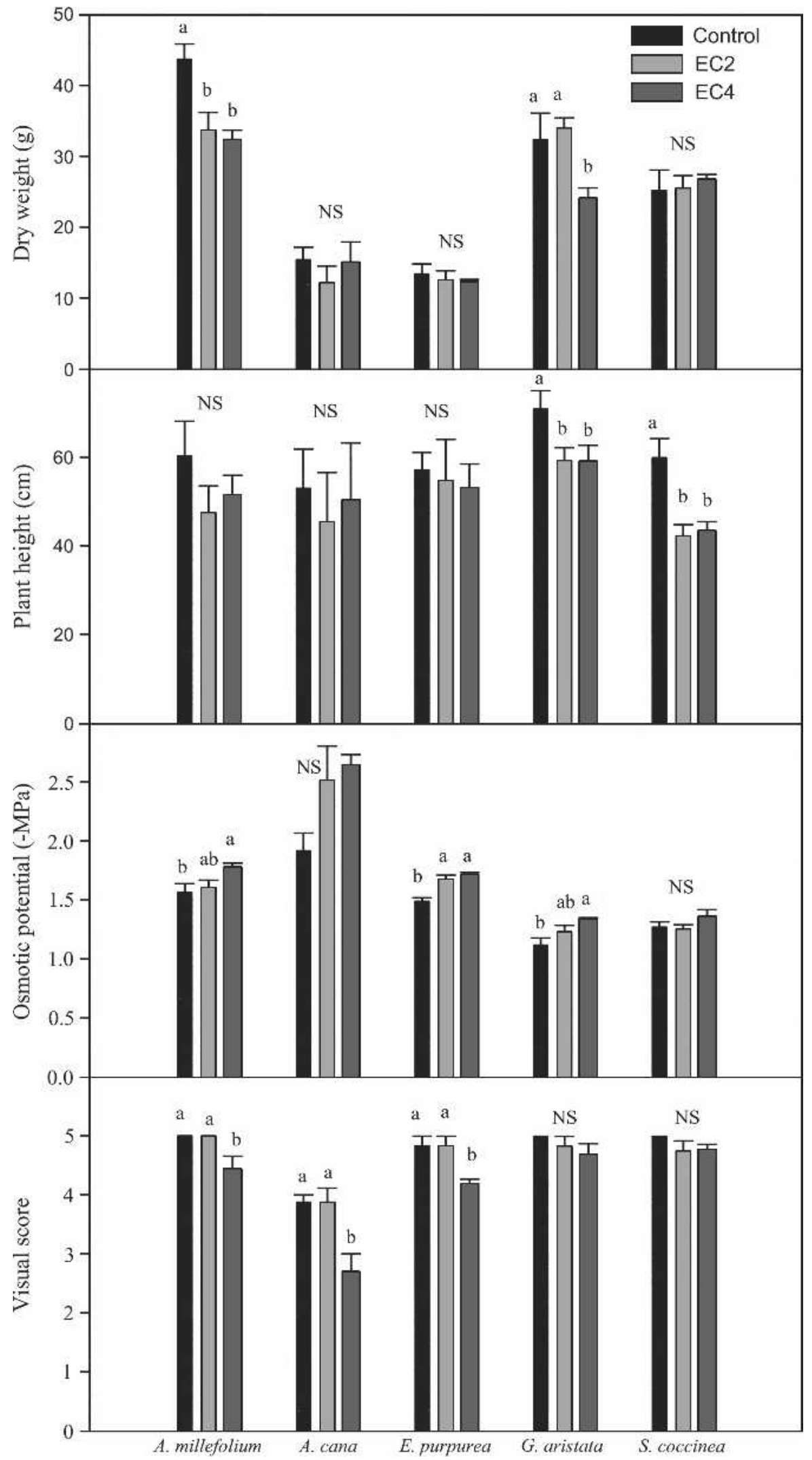

Fig. 2. Effect of electrical conductance (EC) of irrigation solution on dry weight of shoots, plant height, leaf osmotic potential, and visual score of Achillea millefolium, Agastache cana, Echinacea purpurea, Gaillardia aristata, and Salvia coccinea in the fall experiment. Means within each species followed by the same letters are not significantly different, tested by Student-Newman-Keuls multiple comparison at $P=0.05$. Vertical bars represent SE. NS, nonsignificant among treatment. Control, tap water; EC2, EC at $2.0 \mathrm{dS} \cdot \mathrm{m}^{-1} ; \mathrm{EC} 4, \mathrm{EC}$ at $4 \mathrm{dS} \cdot \mathrm{m}^{-1}$. 
irrigation water increased, there were no statistical differences among the three salinity levels. No statistical differences were observed in plant height among the treatments for all species. Leaf $\psi_{\mathrm{S}}$ was lower at $2 \mathrm{dS} \cdot \mathrm{m}^{-1}$ or $4 \mathrm{dS} \cdot \mathrm{m}^{-1}$ for all species. Because only one E. purpurea plant survived at $4 \mathrm{dS} \cdot \mathrm{m}^{-1}$ by the end of the experiment, its $\psi_{\mathrm{S}}$ was not measured. Osmotic adjustment is one of the mechanisms by which many plant species cope with salt and drought stresses. All species in this experiment showed osmotic adjustment at higher salinity levels.

Achiella. millefolium, G. aristata, and $S$. coccinea had visual scores of 4 points or more at elevated salinity levels, which were considered acceptable for landscape performance. A. cana and E. purpurea had the lowest visual scores and were not acceptable even at $2 \mathrm{dS} \cdot \mathrm{m}^{-1}$.

In the fall experiment, shoot dry weight of A. millefolium and $G$. aristata were significantly less at elevated salinity levels compared with the control (Fig. 2), whereas that of A. cana, E. purpurea, and S. coccinea were similar among the treatments. G. aristata and $S$. coccinea plants were shorter when irrigated with solution at $2 \mathrm{dS} \cdot \mathrm{m}^{-1}$ or $4 \mathrm{dS} \cdot \mathrm{m}^{-1}$ compared with the control. Although leaf $\psi_{\mathrm{S}}$ of plants irrigated with water at $4 \mathrm{dS} \cdot \mathrm{m}^{-1}$ was significantly lower compared with the control for A. millefolium, E. purpurea, and G. aristata, but not for A. cana and S. coccinea (Fig. 2), the difference was much smaller compared with the summer experiment (Fig. 1). Also, A. cana and $S$. coccinea had significantly lower leaf $\psi_{\mathrm{S}}$ in plants irrigated with elevated-salinity water in the summer experiment (Fig. 1). These results may indicate that plants in the summer experiment were more stressed than those in the fall, possibly because of the higher temperature and irradiance. Zollinger et al. (2005) also reported that environmental conditions affected plant response to salinity in a number of herbaceous perennials. All species had acceptable visual quality with a score of 4 points or more except for $A$. cana in the fall experiment irrigated at $4 \mathrm{dS} \cdot \mathrm{m}^{-1}$ (Fig. 2).

The average EC of leachate across the species in the same EC treatment increased with time (Fig. 3). In the summer experiment, all plants were flushed $42 \mathrm{~d}$ after the treatment to reduce the EC in root zone. However, the $\mathrm{EC}$ of leachate increased to almost double the salinity of irrigation solution in 2 weeks. The EC of leachate in the fall experiment was lower than that in the summer experiment. This was probably the result of the differences of potting media or irrigation method. The medium used in the summer experiment had a porosity of $17 \%$, whereas that of medium used in the fall was $25 \%$ (unpublished data) containing composted mulch, which contributes to better drainage.

Although grown for the same period of time, plants during the fall experiment grew more than the same plant species during the summer, probably because of the differences in container size and medium. It was reported that growth of Salvia splendens F. Sellow ex

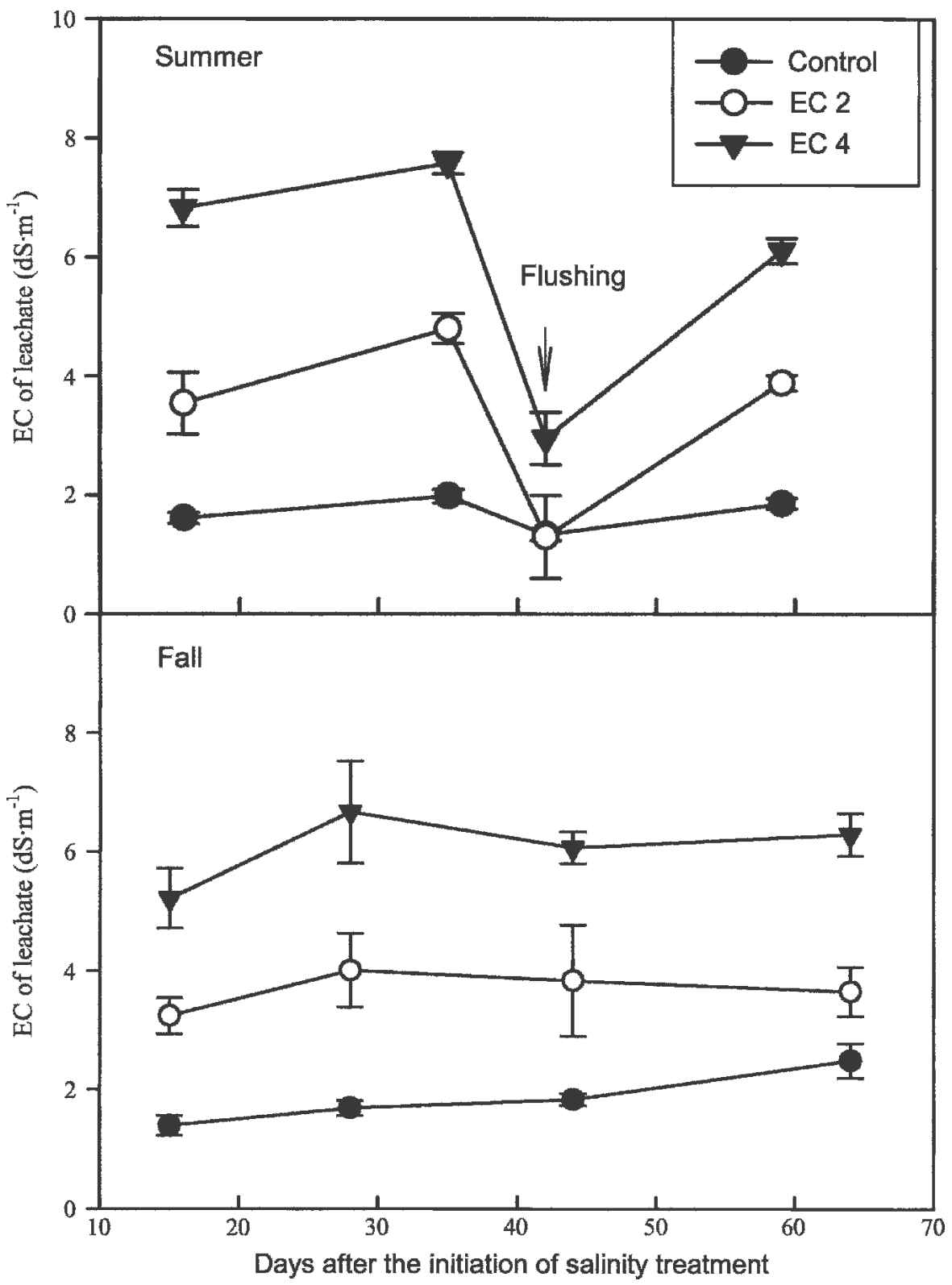

Fig. 3. Effect of electrical conductance (EC) of irrigation solution on the EC of the leachate. Data were pooled across species for each salinity treatment. Medium was flushed with tap water on day 42 in the summer experiment. Vertical bars represent \pm SE.

Roem. \& Schult. was positively correlated with pot size (van Iersel, 1997). However, the relative salt tolerance among tested species was generally consistent. A. millefolium, G. aristata, and $S$. coccinea had relatively high salt tolerance. They may be irrigated with a saline solution up to $4 \mathrm{dS} \cdot \mathrm{m}^{-1}$ under both summer and fall conditions in the greenhouse with acceptable performance with little or no growth reduction. Agastache cana and E. purpurea were salt sensitive and should not be irrigated with saline solution.

Recommended salt tolerance or threshold of salinity for landscape plants should be based primarily on their aesthetic appearance, instead of maximizing growth (Fox et al., 2005), especially for rapidly growing plant species. For example, although a significant reduction of growth in A. millefolium and $G$. aristata was observed under elevated salinity conditions compared with the plants irrigated with tap water, their compact appearance was more desirable and required less maintenance. Although there were no growth differences among the treatments for A. cana (fall experiment), leaf injuries were observed, which are not acceptable for landscaping purposes.

The salinity threshold of these landscape species eventually needs to be confirmed under landscape conditions. The relative salt tolerance determined in the greenhouse studies provides baseline information on plant performance in response to a range of salinity levels and may be used as a reference for salt sensitivity of plants for landscape irrigation with treated effluent. Among the available lists of salt tolerance of landscape plants, information was largely based on empirical observation and the majority was for woody 
ornamentals (Costello et al., 2003). Because plant response to salinity varies not only with plant species, but also with local climate conditions and soil or medium properties (Costello et al., 2003; Fox et al., 2005), care should be taken when using this information with nonpotable water irrigation.

\section{Literature Cited}

Bailey, L.H. and E.Z. Bailey. 1976. Hortus third. A concise dictionary of plants cultivated in the United States and Canada, Macmillan, New York.

Cameron, A., R. Heins, and W. Carlson. 2000. Forcing perennials 102. Firing up perennials The 2000 edition. Greenhouse Grower Magazine, Willoughby, Ohio, and Michigan State Univ., 7-8.

Costello, L.R., E.J. Perry, N.P. Matheny, J.M. Henry, and P.M. Geisel. 2003. Abiotic disorders of landscape plants. A diagnostic guide. Publication 3420 University of California, Agricultural and Natural Resources, Oakland, Calif.

Fox, L.J., J.N. Grose, B.L. Appleton, and S.J. Donohue. 2005. Evaluation of treated effluent as an irrigation source for landscape plants. J. Environ. Hort. 23:174-178.

Johnson, A.M. and T. Whitwell. 1997. Selecting species to develop a field-grown wildflower sod. HortTechnology 7:411-414.
Jordan, L.A., D.A. Devitt, R.L. Morris, and D.S Neuman. 2001. Foliar damage to ornamental trees sprinkler-irrigated with reuse water. Irrig. Sci. 21:17-25.

Khurram, S. and S. Miyamoto. 2005. Seedling growth, leaf injury and ion uptake response of cold-resistant palm species to salinity. J. Environ. Hort. 23:193-198.

Kjelgren, R., L. Rupp, and D. Kilgren. 2000. Water conservation in urban landscapes. HortScience 35:1037-1040.

Nobel, P.S. 1991. Physiochemical and environmental plant physiology. Academic, San Diego, Calif.

Parnell, J.R. 1988. Irrigation of landscape ornamentals using reclaimed water. Proc. Fla. State. Hort. Soc. 101:107-110.

Pasternak, D. and Y.D. Malach. 1994. Crop irrigation with saline water, p. 599-622. In: M. Pessarakli (ed.). Handbook of plant and crop stress. Marcel Dekker New York.

Qian, Y.L., J.M. Fu, J. Klett, and S.E. Newman. 2005. Effects of long-term recycled wastewater irrigation on visual quality and ion concentrations of ponderosa pine. J. Environ. Hort. 23:185-189.

Rhoades, J.D. 1999. Use of saline drainage water for irrigation. Agron. Monogr. no. 38. chap 18 R.W. Skaggs and J. van Schilfgaarck, (eds.), ASA, CSSA, SSSA, Madison, Wis., 18. 615-657.

Rodriguez, D.S. 2005. Developing a scientific basics for wastewater application in the Chihuahuan desert. MS thesis. New Mexico State Univ., Las Cruces.
Ruiz, A., T.W. Sammis, G.A. Picchioni, J.G. Mexal, and W.A. Mackay. 2006. An irrigation scheduling protocol for treated industrial effluent in the Chihuahuan desert. J. AWWA. 98:122-133.

Shillo, R., M. Ding, D. Pasternak, and M. Zaccai. 2002. Cultivation of cut flower and bulb species with saline water. Sci. Hort. 92:41-54.

Sovocool, K., M. Morgan, and D. Bennett. 2006. An in-depth investigation of xeriscape as a water conservation measure. J. AWWA. 98: $82-93$.

Ulery, A.L., J.A. Teed, M.T. van Genuchten, and M.C. Shannon. 1998. Saltdata: A database of plant yield response to salinity. Agron. J. 90:556-562.

van Iersel, M. 1997. Root restriction effects on growth and development of salvia (Salvia splendens). HortScience 32:1186-1190.

Wright, R.D. 1986. The pour-through nutrient extraction procedure. HortScience 21:227229.

Wu, L., X. Guo, and A. Harivandi. 2001. Salt tolerance and salt accumulation of landscape plants irrigated by sprinkler and drip irrigation systems. J. Plant Nutr. 24:1473-1490.

Zhang, D., A.M. Armitage, J.M. Affolter, and M.A. Dirr. 1996. Environmental control of flowering and growth of Achillea millefolium L. 'Summer Pastels'. HortScience 31:364-365.

Zollinger, N., T. Cerny-Koenig, R. Kjelgren, R. Koenig, and K. Kopp. 2005. Salinity tolerance of eight ornamental herbaceous perennials. HortScience 40:1034-1035. 